Agro Ekonomi Vol. 27/No. 2, Desember 2016

\title{
SENSITIVITAS PRODUKSI PADI TERHADAP PERUBAHAN IKLIM DI INDONESIA TAHUN 1974-2015
}

\section{The Sensitivity of Paddy's Production to Climate Change in Indonesia on 1974 $-2015$}

\author{
Yanti Nurhayanti, Moko Nugroho \\ Program Pascasarjana Ilmu Ekonomi, Universitas Indonesia \\ Jl. Prof. Dr, Sumitro Djojohadikusumo, Depok, Jawa Barat 16424 \\ nugroho.moko@gmail.com
}

Diterima tanggal : 2 September 2016 ; Disetujui tanggal : 3 Oktober 2016

\begin{abstract}
The occurrence of climate change disrupts the productivity of paddy in Indonesia. Disruption of the paddy's production has an impact on the availability of foodstuffs, considering paddy as staple food Indonesia society. This study aims to analyze the impact of climate change on productivity of paddy in the central acreage of paddy in period 1974-2015 by using four different climate variables. The data used are secondary data collected from Agency of Central for Statistics (BPS), Ministry of Agriculture, and National Oceanic and Atmospheric Administration (NOAA). Estimation method using data panels with Random Effect models (REM). The results showed the productivity of paddy in Indonesia are more sensitive to changes in rainfall and maximum temperature $\left(T_{\max }\right)$ compared to the average temperature $\left(T_{\text {ave }}\right)$ and the minimum temperature $\left(T_{\text {min }}\right)$. Increased rainfall and Tmax positively impact the productivity of paddy until a specific turning point, then after that point will give the opposite impact. As for the turning point for the precipitation of 10,177 Inc./year, while Tmax on 31,35 ${ }^{\circ} \mathrm{C}$. Simple simulation results demonstrate the increase in rainfall in the upper turning point of $1 \%$ will reduce the productivity of paddy amounted $0,00796 \%$ ceteris peribus. While the maximum temperature rise above the turning point of $1 \%$ will reduce the productivity of paddy as much as 0,09039\% ceteris peribus.
\end{abstract}

Keyword : climate change, maximum temperature, paddy's production, precipitation

\section{INTISARI}

Terjadinya perubahan iklim mengganggu produktivitas padi di Indonesia. Terganggunya produksi padi berdampak pada ketersediaan bahan pangan, mengingat padi sebagai bahan pangan pokok masyarakat Indonesia. Studi ini bertujuan untuk menganalisis dampak perubahan iklim terhadap produktivitas padi pada daerah sentra padi di Indonesia periode tahun 1974-2015 dengan menggunakan empat variabel iklim yang berbeda. Data yang digunakan adalah data sekunder yang dikumpulkan dari Badan Pusat Statistik (BPS), Kementerian Pertanian, dan National Oceanic and Atmospheric Administration (NOAA). Metode estimasi menggunakan data panel dengan Random Effect Model (REM). Hasil penelitian menunjukkan produktivitas padi di Indonesia lebih sensitif terhadap perubahan curah hujan dan suhu maksimum ( $\left.\mathrm{T}_{\max }\right)$ dibandingkan dengan suhu rata-rata $\left(\mathrm{T}_{\text {ave }}\right)$ dan suhu minimum $\left(\mathrm{T}_{\min }\right)$. Peningkatan curah hujan dan $\mathrm{T}_{\max }$ berdampak positif terhadap produktivitas padi sampai pada titik balik tertentu, kemudian setelah titik tersebut akan memberikan 
dampak yang sebaliknya. Adapun titik balik untuk curah hujan sebesar 10,177 inc/tahun, sementara $\mathrm{T}_{\max }$ pada $31,35^{\circ} \mathrm{C}$. Hasil simulasi sederhana menunjukkan kenaikan curah hujan di atas titik balik sebesar $1 \%$ akan mengurangi produktivitas padi sebesar $0,00796 \%$ ceteris peribus. Sementara kenaikan suhu maksimum di atas titik balik sebesar $1 \%$ akan mengurangi produktivitas padi sebanyak $0,09039 \%$ ceteris peribus.

Kata kunci : curah hujan, perubahan iklim, produksi padi, suhu maksimum

\section{PENDAHULUAN}

Sektor pertanian merupakan salah satu sektor penggerak perekonomian yang berisiko akibat adanya perubahan iklim. Beberapa kategori perubahan iklim yang dapat menurunkan produksi hasil pertanian seperti suhu ekstrim, gelombang panas, kekeringan, badai, hujan hingga mengakibatkan banjir. Adanya perubahan iklim ini dikhawatirkan akan mendatangkan permasalahan yang serius terhadap keberlanjutan pembangunan pertanian di Indonesia, di antaranya, penurunan produktivitas dan produksi hasil pertanian, terjadinya degradasi sumber daya lahan potensi pertanian dan ketersediaan air yang mengakibatkan penurunan tingkat kesuburan tanah, variabilitas dan perubahan iklim yang mengakibatkan banjir dan kekeringan, serta terjadinya alih fungsi dan fragmentasi lahan pertanian (Surmaini, Runtunuwu dan Las, 2011).

Dampak yang terlihat nyata akibat perubahan iklim yaitu terjadinya lahan puso akibat banjir dan kekeringan. Adanya lahan puso akibat banjir dan kekeringan tentunya akan berdampak pada berkurangnya lahan tanaman padi, yang selanjutnya dapat mengurangi hasil produksi padi. Kementerian Pertanian (2012) mencatat luas lahan tanaman padi yang terkena banjir, kekeringan, dan serangan hama penyakit berturut-turut mencapai 333.000 ha, 319.500 ha dan 428.600 ha dengan kehilangan hasil padi sebesar masingmasing 997.300, 984.200, dan 352.300 ton.

Beberapa studi tentang perubahan iklim di antaranya kuantifikasi dampak perubahan iklim terhadap konflik sosial di masyarakat (Burke, Miguel, Satyanath, Dykema, and Lobell, 2009; O'Louglin, Witmer, Linke, Laing, Gettelman, and Dudhia, 2012; Scheffran, Brzoska, Kominek, Link, Schilling, 2012; Hsiang, Burke, and Migue1, 2013; Hsiang and Burke, 2014), dampak perubahan iklim terhadap nilai lahan pertanian, profitabilitas, dan efisiensi produksi (Schlenker, Hanemann, and Fisher, 2006; Auffhammer, Ramanathan, and Vincent, 2006; Deschenes and Greenstone, 2007; Welch, Vincent, Auffhammer, Moya, and Dawe, 2010). Pada umumnya studi tersebut mengembangkan metode pengukuran, diskusi, dan debat ukuran perubahan iklim terhadap beberapa aspek kehidupan. 
Isu yang menarik dan masih dalam perdebatan adalah bagaimana menentukan kuantifikasi perubahan iklim yang terbaik sehingga estimasi dampak perubahan iklim dapat teridentifikasi secara kredibel. Beberapa literatur yang ada, ukuran statistik untuk perubahan iklim terhadap produksi padi diukur dari suhu rata-rata $\left(\mathrm{T}_{\text {ave }}\right)$, radiasi, dan curah hujan. Namun studi terbaru menunjukkan produktivitas padi di Asia yang beriklim tropis/subtropis sangat sensitif terhadap suhu minimun $\left(\mathrm{T}_{\text {min }}\right)$ dan suhu maksimum $\left(\mathrm{T}_{\max }\right)$ (Welch, Vincent, Auffhammer, Moya, and Dawe, 2010). Bukti empiris menunjukkan $\mathrm{T}_{\text {min }}$ dan $\mathrm{T}_{\text {max }}$ berdampak berbeda pada perkembangan tanaman (Wassmann, Jagadish, Heuer, Ismail, Redona, Serraj, Singh, Howel, Pathak, and Sumfleth, 2009). $\mathrm{T}_{\max }$ selama proses penyerbukan tanaman padi dapat menurunkan produktivitas padi karena terjadi penurunan tingkat kesuburan tanaman. Namun, studi lain dapat membuktikan produktivitas padi lebih sensitif terhadap $\mathrm{T}_{\text {min }}$ daripada $\mathrm{T}_{\text {max }}$ (Peng, Huang, Sheehy, Laza, Visperas, Zhong, Centeno, Khush, and Cassman, 2004).

Dilihat dari pendekatan model estimasi yang digunakan, terdapat variasi model dalam mengestimasi dampak perubahan iklim terhadap produktivitas hasil pertanian. Sebagaimana studi yang dilakukan Welch, Vincent, Auffhammer, Moya, and Dawe (2010), hubungan antara iklim dan produksi padi bersifat linear.
Sementara studi Schlenker and Roberts (2009), menunjukkan hubungan yang tidak linear dan tidak simetris. Ada juga studi yang menunjukkan iklim merupakan variasi spesifikasi model dari suhu dan curah hujan (Tack, Barkley, and Nalley, 2015).

Dalam rangka deteksi dini kondisi ketersediaan pangan, analisis dampak perubahan iklim terhadap produktivitas padi di Indonesia dipandang perlu dilakukan sebagai langkah awal penanggulangannya. Kuantifikasi variabel iklim dan model persamaan yang terbaik merupakan salah satu informasi yang diperlukan dalam menghitung seberapa besar dampak kehilangan produksi padi di Indonesia ketika terjadi perubahan iklim. Penelitian ini bertujuan untuk melakukan kuantifikasi model iklim dan menganalisis dampak perubahan iklim terhadap produktivitas padi di Indonesia. Diharapkan dengan adanya penelitian ini dapat memahami bagaimana dampak perubahan iklim terhadap risiko yang dihadapi pada produktivitas padi di Indonesia sebagai formulasi kebijakan dalam menjaga ketersediaan pangan.

Secara teori, fungsi produksi pertanian, $h=f(x, z)$, dimana $x$ adalah vektor input produksi (seperti luas lahan, labor, dan kapital) dan $\mathrm{z}$ adalah vektor faktor eksogen yang mempengaruhi produksi. Dalam hal ini z adalah iklim yang merupakan faktor produksi non-cost. Dengan pendekatan maksimisasi profit 
terhadap biaya, diperoleh fungsi profit dengan output dan input produksi yang optimum. Dari fungsi profit tersebut dapat diperoleh persamaan supply yang dapat menggambarkan respon produsen terhadap perubahan iklim yakni $\mathrm{q}^{*}=\mathrm{g}(\mathrm{x}, \mathrm{z})$. Ketika terjadi perubahan iklim atau iklim tidak normal $(\mathrm{z} \neq 0)$, iklim akan menurunkan output dan menaikkan harga output.

Ahli agronomi dan ekonomi pertanian menyatakan kuantifikasi iklim yang mempengaruhi produksi pertanian diukur dari suhu dan curah hujan (Oury, 1965), sehingga iklim (z) dapat dituliskan menjadi $z=g$ (suhu, curah hujan). Dengan demikian persamaan fungsi produksi pertanian (h) menjadi :

$$
h=f(x, g(\text { suhu, curah hujan })) .
$$

Mendelson, Nordhaus, William, and Shaw (1994), melakukan studi dampak pemanasan global pada sektor pertanian di Amerika Serikat dengan menggunakan variabel iklim, harga lahan pertanian, pendapatan, variabel ekonomi lainnya, dan ukuran geofisika (temperatur, curah hujan, kelembapan) di 3.000 wilayah Amerika tahun 1951-1980. Hasil studinya menunjukkan suhu tinggi yang terjadi di setiap musim, kecuali musim gugur, telah menurunkan produktivitas pertanian. Sementara itu, curah hujan yang tinggi di luar musim gugur akan meningkatkan produktivitas pertanian.
Schlenker, Hanemann, and Fisher (2006), melakukan studi dampak pemanasan global terhadap sektor pertanian di Amerika Serikat menggunakan data besaran iklim di sektor pertanian, kesuburan tanah, dan variabel sosial ekonomi di wilayah timur Amerika selama 100 tahun. Hasil studi menunjukkan 75\% dari sampel wilayah memberikan variasi dampak, mulai dari dampak positif sampai dampak kerugian yang besar. Namun secara agregat, terjadi dampak kerugian yang besar pada sektor pertanian akibat adanya pemanasan global.

Deschenes and Greenstone (2007), mengukur dampak ekonomi yang terjadi akibat adanya perubahan iklim pada sektor pertanian di Amerika Serikat dengan memperkirakan pengaruh variasi suhu dan curah hujan dari tahun ke tahun terhadap keuntungan pertanian. Secara rata-rata, perkiraan jangka panjang menunjukkan bahwa perubahan iklim ternyata akan meningkatkan keuntungan pertanian sebesar 3,4\% dari keuntungan tahunan. Namun kisaran dampak yang terjadi antara $-1,8 \%-4,0 \%$ dengan tingkat kepercayaan $95 \%$. Dengan demikian dapat terlihat adanya dampak positif dan negatif terhadap keuntungan pertanian. Hal ini juga dipertegas dengan adanya heterogen dampak antar wilayah, seperti di California yang diprediksi perubahan iklim akan menurunkan keuntungan pertanian sebesar $50 \%$. 
Studi Schlenker and Robert (2009), suhu memberikan dampak yang tidak linear terhadap produktivitas pertanian jika terjadi perubahan iklim. Studi yang dilakukan menggunakan data panel per wilayah untuk 3 komoditas pertanian (kedelai, jagung dan kapas). Hasilnya menunjukkan adanya batasan suhu yang masih memberikan dampak positif pada produksi jagung, kedelai, dan kapas. Batasan suhu tersebut adalah $29^{\circ} \mathrm{C}$ untuk jagung, $30^{\circ} \mathrm{C}$ untuk kedelai, dan $32^{\circ} \mathrm{C}$ untuk kapas, di atas batas tersebut dapat memberikan efek yang negatif terhadap produksi komoditas pertanian tersebut.

Welch, Vincent, Auffhammer, Moya, Doberman, and Dawe (2010), menunjukkan suhu dan radiasi berdampak signifikan pada fase penyerbukan dan fase pematangan tanaman padi di negara yang beriklim tropis/subtropis. Suhu minimum berdampak negatif terhadap produksi padi, sedangkan suhu maksimum berdampak positif terhadap produksi padi. Sementara dampak radiasi bervariasi terhadap fase pertumbuhan tanaman padi. Kombinasi dampak dari suhu maksimum, suhu minimum, dan radiasi lebih berdampak pada saat musim panen daripada musim tanam.

Penelitian Tack, Barkley, and Nalley (2015) menggunakan berbagai spesifikasi model statistik dalam mengukur hubungan yang kompleks antara variabel iklim dengan produktivitas gandum. Hasil studinya menunjukkan efek dari suhu bervariasi di fase perkembangan tanaman. Dampak penurunan produksi terbesar terjadi pada saat musim dingin dan panas ekstrim di musim semi.

Berdasarkan tinjauan literatur di atas umumnya ukuran suhu dan curah hujan merupakan variabel yang memberikan dampak terhadap produksi di sektor pertanian. Untuk distribusi suhu, maka ukuran suhu dibuat lebih detail menjadi suhu minimum, suhu rata-rata, dan suhu maksimum. Sementara variabel dependen sebagai output produksi yang digunakan yaitu besaran produktivitas padi.

\section{METODE PENELITIAN}

\section{Data yang Digunakan}

Data produktivitas padi yang digunakan merupakan nilai rata-rata produksi padi per hektar secara tahunan dalam kuintal per hektar. Sedangkan data suhu dalam celcius meliputi: (1) suhu minimum, (2) suhu rata-rata, dan (3) suhu maksimum. Data suhu merupakan nilai rata-rata dari suhu harian dalam satu tahun. Sementara data curah hujan dalam 0,1 inchi per tahun yang merupakan kumulatif curah hujan harian dalam satu tahun.

Data produktivitas padi dipilih pada sepuluh provinsi sentra padi di Indonesia dengan pertimbangan kontribusi total sepuluh provinsi tersebut mencapai $80 \%$ produksi padi nasional. Sepuluh provinsi tersebut meliputi Sumatera Utara, Sumatera 
Barat, Lampung, Jawa Barat, Jawa Tengah, Jawa Timur, Kalimantan Selatan, Sulawesi Selatan, Sulawesi Utara, dan NTB. Data produktivitas padi bersumber dari Badan Pusat Statistik dan Kementerian Pertanian. Adapun data suhu dan curah hujan bersumber dari National Oceanic and Atmospheric Administration (NOAA). Sementara periode tahun yang digunakan selama 42 tahun, yaitu dari 1974 sampai dengan 2015.

\section{Spesifikasi Model}

Spesifikasi model yang digunakan dalam studi ini mengacu pada model Welch, Vincent, Auffhammer, Moya, Doberman, and Dawe (2010) dan Tack, Barkley, and Nalley (2015), yaitu :

$\ln y_{i t}=\alpha_{0}+\alpha_{1} t+\alpha_{2} t^{2}+f\left(z_{i t}\right)+\varepsilon_{i t}$

dimana ln $\mathrm{y}_{\mathrm{it}}$ menunjukkan logaritma produktivitas padi pada provinsi $i$ untuk periode $t, t$ dan $t^{2}$ merupakan variabel tren untuk menangkap input dan perubahan teknologi pertanian, $f\left(z_{i t}\right)$ merupakan ukuran iklim pada provinsi $i$ untuk periode $t$, dan $\varepsilon_{i t}$ error term.

Ukuran/proxy iklim yang digunakan pada penelitian ini mengacu pada studi yang dilakukan Schlenker and Robert (2009), yaitu :

$f\left(z_{i t}\right)=\beta_{1} T_{a v \theta_{i t}}+\delta_{i} R_{i t}$

$$
\begin{aligned}
& f\left(z_{i t}\right)=\beta_{1} T_{\text {ave } i t}+\beta_{2} T_{\text {ave } i t}{ }^{2}+ \\
& \delta_{1} R_{i t}+\delta_{2} R_{i t}{ }^{2} \\
& f\left(z_{i t}\right)=\beta_{1} T_{\text {min }_{i t}}+\beta_{2} T_{\text {max }_{i t}}+ \\
& \delta_{1} R_{i t} \\
& f\left(z_{i t}\right)=\beta_{1} T_{\min _{i t}}+\beta_{2} T_{\max _{i t}}+ \\
& \beta_{3} T_{\text {minitit }^{2}}{ }^{2}+\beta_{4} T_{\max _{i t}}{ }^{2}+\delta_{1} R_{i t}+ \\
& \delta_{2} R_{i t}{ }^{2}
\end{aligned}
$$

dimana $T_{\text {ave }}$ suhu rata-rata, $T_{\min }$ suhu minimum, $\mathrm{T}_{\max }$ suhu maksimum, dan $\mathrm{R}_{\mathrm{it}}$ curah hujan.

Dengan demikian terdapat empat model spesifikasi yang akan dilakukan pada penelitian ini, yaitu :

$$
\begin{aligned}
& \ln y_{i t}=\alpha_{0}+\alpha_{1} t+\alpha_{2} t^{2}+ \\
& \beta_{1} T_{a v \theta_{i t}}+\delta_{i} R_{i t}+\varepsilon_{i t} \\
& \ln y_{i t}=\alpha_{0}+\alpha_{1} t+\alpha_{2} t^{2}+ \\
& \beta_{1} T_{\text {ave } i t}+\beta_{2} T_{\text {ave } i t}{ }^{2}+\delta_{1} R_{i t}+ \\
& \delta_{2}{R_{i t}}^{2}+\varepsilon_{i t}
\end{aligned}
$$

$$
\ln y_{i t}=\alpha_{0}+\alpha_{1} t+\alpha_{2} t^{2}+
$$$$
\beta_{1} T_{\min _{i t}}+\beta_{2} T_{\max _{i t}}+\delta_{1} R_{i t}+\varepsilon_{i t}
$$

$$
\begin{aligned}
& \ln y_{i t}=\alpha_{0}+\alpha_{1} t+\alpha_{2} t^{2}+ \\
& \beta_{1} T_{\text {min } i t_{i t}}+\beta_{2} T_{\max _{i t}}+\beta_{3} T_{\text {minit }_{i t}}{ }^{2}+ \\
& \beta_{4} T_{\text {max }_{i t}}{ }^{2}+\delta_{1} R_{i t}+\delta_{2} R_{i t}{ }^{2}+\varepsilon_{i t}
\end{aligned}
$$

\section{Metode Estimasi}

Metode estimasi model dalam penelitian ini menggunakan data panel. Penggunaan data panel akan memberikan lebih banyak informasi, variability, dan degree of freedom terhadap model. Ada 
tiga macam pendekatan pada data panel yaitu pendekatan kuadrat terkecil (pooled least square) atau commond effect model (CEM), pendekatan dampak tetap (fixed effect model/FEM), dan pendekatan dampak acak (random effect model/REM). Model fixed effect memperlakukan intersep model sebagai parameter regresi. Model random effect memperlakukan intersep pada model sebagai komponen gangguan acak.

Untuk mendapatkan regresi data panel yang terbaik antara $C E M, F E M$, dan $R E M$, dilakukan uji $\mathrm{F}$ yang digunakan untuk memilih antara CEM dan FEM, uji Lagrange Multiplier untuk memilih antara CEM dan REM, dan uji Hausman untuk memilih antara $F E M$ dan REM. Selanjutnya akan dilakukan estimasi parameter dengan model regresi data panel yang digunakan sebagaimana hasil uji di atas. Dari empat model spesifikasi diperbandingkan dampak variabel iklim terhadap produktivitas padi.

\section{HASIL DAN PEMBAHASAN}

\section{Analisis Deskriptif}

Data yang dihimpun untuk estimasi parameter secara ringkas disajikan dalam Tabel 1.
Selama periode 42 tahun, produktivitas padi memiliki rentang nilai maksimum dan minimum yang relatif tinggi. Nilai maksimumnya lebih dari dua kali lipat dari nilai minimum. Dilihat dari nilai standar deviasinya pun cukup tinggi yang mencapai $9 \mathrm{kw} / \mathrm{ha}$. Informasi tersebut menunjukkan antar sentra produksi padi memiliki variasi yang cukup besar. Perbedaan lingkungan tumbuh antar daerah kemungkinan besar menjadi sumber variasi yang terjadi. Untuk variabel iklim, variabel curah hujan lebih berfluktuasi antar provinsi sentra padi dibandingkan dengan variabel suhu. Dari ketiga ukuran suhu, rentang nilai maksimum dan minimum untuk suhu maksimum lebih tinggi dibandingkan dengan variabel suhu rata-rata ataupun suhu minimum. Namun variasi ketiga ukuran suhu antar provinsi sentra padi tersebut memiliki variasi yang relatif kecil yakni berkisar $0,7{ }^{0} \mathrm{C}-0,99{ }^{\circ} \mathrm{C}$. Sementara curah hujan memiliki nilai rentang maksimum dan minimum yang relatif besar. Begitu juga nilai variasi curah hujan antar provinsi sentra padi

Tabel 1. Statistik deskriptif parameter

\begin{tabular}{lrrrr}
\hline \multicolumn{1}{c}{ Variabel } & \multicolumn{1}{c}{ Min } & \multicolumn{1}{c}{ Max } & \multicolumn{1}{c}{ Mean } & \multicolumn{1}{c}{ SD } \\
\hline Produktivitas $(\mathrm{Kw} / \mathrm{Ha})$ & 18,00 & 63,00 & 43,751 & 9,0526 \\
Suhu $\left({ }^{\circ} \mathrm{C}\right)$ & 24,06 & 28,40 & 27,048 & 0,7431 \\
Curah hujan $(0.1$ inc) & 0,00 & 278,57 & 56,060 & 52,737 \\
Suhu minimum $\left({ }^{\circ} \mathrm{C}\right)$ & 18,09 & 25,34 & 23,160 & 0,9421 \\
Suhu maksimum $\left({ }^{\circ} \mathrm{C}\right)$ & 28,26 & 33,63 & 31,228 & 0,9971 \\
\hline
\end{tabular}

Sumber : BPS, Kementan, NOAA (diolah) 


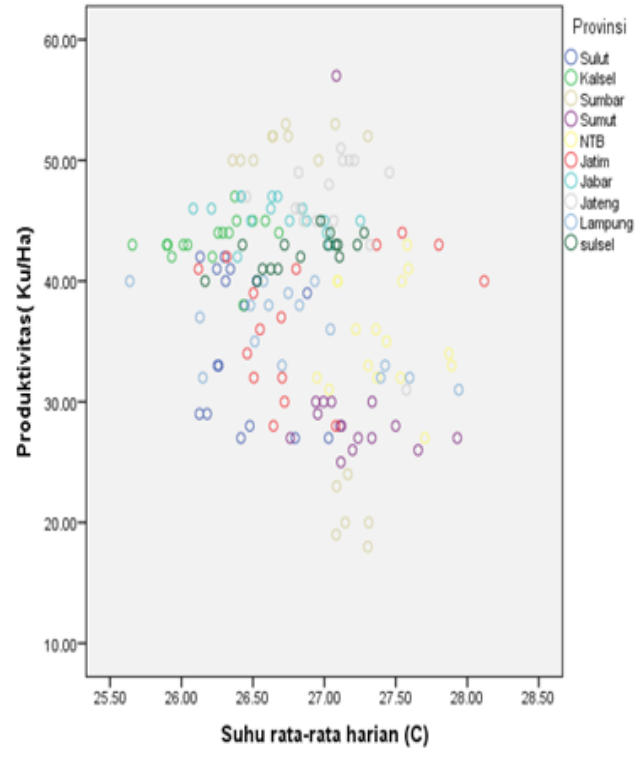

Gambar 1. Scatter plot produktivitas padi dengan suhu rata-rata

relatif besar yang ditunjukkan dengan nilai standar deviasi yang besar.

Hasil scatter plot antara produktivitas padi dan variabel iklim memiliki gambaran yang berbeda untuk setiap ukuran iklim dan daerah provinsi sentra padi. Misalnya untuk provinsi Jawa Barat, dibandingkan dengan provinsi lainnya produktivitas padi lebih tinggi, tetapi suhu udara lebih rendah baik untuk ukuran suhu rata-rata, suhu minimum dan suhu maksimum. Peningkatan suhu ratarata terhadap produktivitas padi di Jawa Barat relatif turun, peningkatan suhu minimum relatif naik dan suhu maksimum relatif stabil. Sementara peningkatan curah hujan relatif berfluktuatif. Lebih lanjut hasil scatter plot antara produktivitas padi dan variabel iklim terlihat pada gambar berikut ini.

Secara umum gambar 1 dan 2 menjelaskan sebaran produktivitas padi

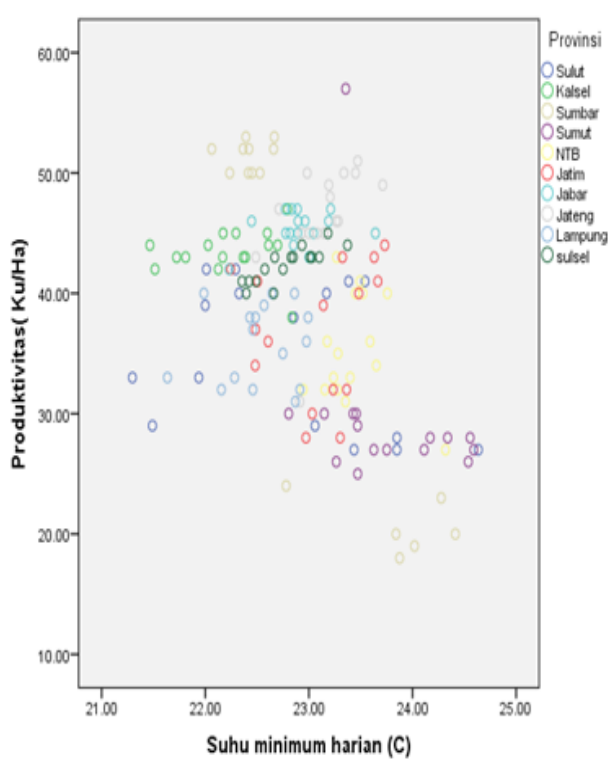

Gambar 2. Scatter plot produktivitas padi dengan suhu minimum

dengan kondisi suhu rata-rata dan suhu minimum sebagai ukuran iklim pada setiap provinsi sentra padi. Di setiap provinsi sentra padi menunjukkan pola mendatar artinya tidak terjadi tren untuk setiap kenaikan suhu rata-rata terhadap produktivitas padi. Namun demikian ada beberapa provinsi yang menunjukkan fluktuasi produktivitas padi pada saat terjadi kenaikan suhu rata-rata atau suhu minimum seperti provinsi Jawa Timur dan Lampung.

Gambar 3 dan 4 menjelaskan sebaran produktivitas padi dengan kondisi suhu maksimum dan curah hujan sebagai ukuran iklim pada setiap provinsi sentra padi. Gambar 3 dan 4 sedikit berbeda dengan Gambar 1 dan 2, dimana sebaran data menunjukkan pola yang beragam pada setiap terjadi peningkatan suhu maksimum 


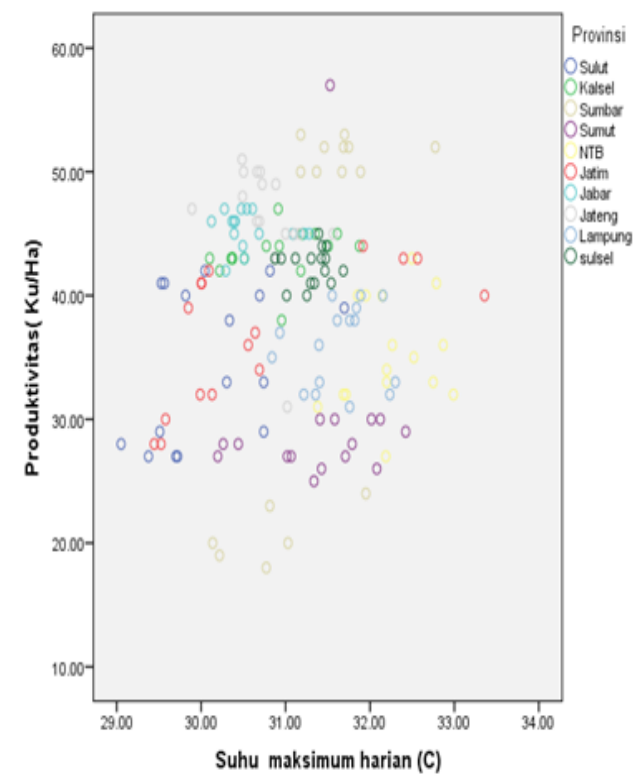

Gambar 3. Scatter plot produktivitas padi dengan suhu maksimum

ataupun curah hujan terhadap produktivitas padi di seluruh provinsi sentra padi.

\section{Validasi Model}

Pengujian Lagrange Multiplier berdasarkan residual ordinary least square (OLS) untuk pemilihan antara CEM atau REM dengan hipotesis : $\mathrm{H}_{0}: \sigma_{u}^{2}=0$ dan $\mathrm{H}_{1}: \sigma_{u}^{2} \neq 0$. Hasil uji seperti pada tabel 2.

Tabel 2. Hasil Uji Lagrange Multiplier Multiplier

\begin{tabular}{lll}
\hline Uji LM & Model 1 & Model 2 \\
\hline chibar2 (01) & 3851,75 & 2759,43 \\
& $(0,0000)$ & $(0,0000)$ \\
Uji LM & Model 3 & Model 4 \\
chibar2 (01) & 3857,37 & 3231,46 \\
& $(0,0000)$ & $(0,0000)$ \\
\hline
\end{tabular}

Dari hasil uji Lagrange menunjukkan keempat model Ho di tolak dengan tingkat

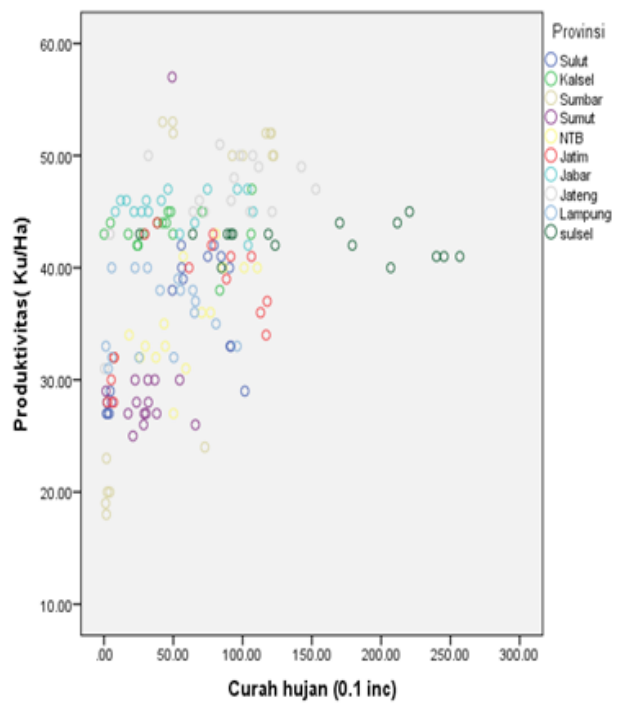

Gambar 4. Scatter plot produktivitas padi dengan curah hujan

signifikansi $1 \%$. Sehingga model yang dipilih adalah REM. Selanjutnya dilakukan pengujian Hausman untuk pemilihan antara FEM atau REM. Hasil uji seperti pada tabel 3.

Tabel 3. Hasil Uji Hausman

\begin{tabular}{lcc}
\hline Uji Hausman & Model 1 & Model 2 \\
\hline chi2 (3) & 0,30 & 1,12 \\
& $(0,9599)$ & $(0,7721)$ \\
\hline Uji Hausman & Model 3 & Model 4 \\
\hline chi2 (3) & 0,29 & 0,15 \\
& $(0,9907)$ & $(0,9996)$ \\
\hline
\end{tabular}

Hasil uji hausman menunjukkan REM sebagai model estimasi yang dipilih. Sehingga regresi model dilakukan dengan REM.

Berdasarkan dimensi data yang digunakan pada penelitian ini memiliki dimensi $\mathrm{T}$ (jumlah time series $)=42$ dan $\mathrm{N}($ jumlah cross section $)=10$, maka 
kemungkinan hanya ada sedikit perbedaan antara nilai parameter yang diestimasi dengan FEM dan REM (Schlenker and Roberts, 2009). Hal yang sama juga diungkapkan Welch, Vincent, Auffhammer, Moya, Doberman, and Dawe (2010) bahwa hasil estimasi dampak suhu terhadap produksi padi di Asia menggunakan $F E M$ dan REM relatif sama selama variabel kontrol yang digunakan di antara kedua model tersebut juga sama. Dengan demikian estimasi parameter untuk model yang ada pada penelitian ini tidak akan berbeda jauh apabila menggunakan FEM dan REM. Meskipun demikian dalam penelitian ini akan mengunakan estimasi parameter dengan REM sesuai dengan hasil uji hausman.

\section{Hasil Estimasi}

Dari hasil estimasi pada tabel 3 terlihat bahwa variabel curah hujan merupakan variabel iklim yang berpengaruh signifikan secara parsial untuk keempat model dalam mempengaruhi produktivitas padi di Indonesia. Pada spesifikasi model linear, koefisien estimasi curah hujan dapat diinterpretasikan sebagai elastisitas curah hujan terhadap produktivitas padi, dimana setiap kenaikan 1\% curah hujan akan meningkatkan produktivitas padi $0,011 \%$. Namun untuk spesifikasi model non-linear, peningkatan curah hujan akan berdampak positif sampai pada titik tertentu, setelah titik tertentu tersebut peningkatan curah hujan akan berdampak negatif terhadap produktivitas padi. Hasil ini sejalan dengan studi Schlenker and Robert (2009), bahwa curah hujan secara statistik signifikan membentuk kurva inverted-U shape terhadap produktivitas padi. Hasil estimasi model 4, titik balik curah hujan selama satu tahun di Indonesia adalah sebesar 10,177 inc, di atas angka tersebut perlu diwaspadai adanya potensi banjir yang dapat menyebabkan gagal panen dan merangsang organisme pengganggu tanaman (OPT).

Hasil estimasi dengan REM, variabel iklim ditunjukkan pada Tabel 3. Produktivitas padi kurang sensitif terhadap peningkatan suhu rata-rata. Berdasarkan uji parsial, peningkatan suhu rata-rata tidak signifikan mempengaruhi produktivitas padi baik untuk model linear maupun model non-linear. Hasil ini sejalan dengan studi Schlenker and Robert (2009), bahwa kuantifikasi variabel iklim pada daerah yang beriklim tropis lebih sesuai menggunakan suhu minimum dan suhu maksimum daripada menggunakan suhu rata-rata.

Hasil estimasi dampak suhu minimum dan suhu maksimum terhadap produktivitas padi di Indonesia menghasilkan dampak yang cenderung berlawanan. Pada model 3, suhu minimum berdampak negatif terhadap produktivitas padi sedangkan suhu maksimum berdampak positif meskipun secara uji parsial untuk kedua variabel tersebut tidak signifikan. 
Tabel 4. Hasil Simulasi

\begin{tabular}{lcccc}
\hline \multicolumn{1}{c}{ Variabel } & Titik & \multicolumn{3}{c}{ Kenaikan (\%) } \\
& Optimum & 1 & 5 & 10 \\
\hline Curah Hujan $(0.1$ inc) & 10,18 & $-0,0079$ & $-0,0081$ & $-0,0083$ \\
Suhu Maks $\left({ }^{\circ} \mathrm{C}\right)$ & 31,15 & $-0,0903$ & $-1,1065$ & $-2,3236$ \\
\hline
\end{tabular}

Pada model non-linear, model 4, suhu maksimum lebih berdampak pada produktivitas padi dibandingkan dengan suhu minimum. Hasil model 4 juga menunjukkan adanya titik balik pada peningkatan suhu maksimum terhadap produktivitas padi di Indonesia, dimana setiap peningkatan suhu maksimum akan meningkatkan produktivitas padi sampai titik tertentu, setelah itu peningkatan suhu maksimum akan menurunkan produktivitas padi. Adapun titik balik suhu maksimum berdasarkan hasil estimasi sebesar $31,35^{\circ} \mathrm{C}$.

Variabel tren bernilai positif dan signifikan baik model linear ataupun model non-linear. Variabel tren sebagai proxy input dan tingkat perubahan teknologi pertanian secara signifikan meningkatkan produktivitas padi, artinya teknologi produksi dan budidaya yang diterapkan selama empat dekade terakhir secara umum telah meningkatkan produktivitas padi. Namun demikian, peningkatan produktivitas padi akibat kemajuan teknologi tertentu akan mencapai titik balik dan dibutuhkan teknologi-teknologi baru lagi dalam meningkatkan produktivitasnya.

\section{Simulasi Dampak}

Berdasarkan hasil estimasi, curah hujan dan suhu maksimum merupakan faktor yang berpengaruh signifikan terhadap produktivitas padi di Indonesia. Simulasi dampak dilakukan dengan kenaikan suhu maksimum dan curah hujan di atas titik optimum ceteris peribus. Kenaikan curah hujan dan suhu maksimum sebesar $1 \%, 5 \%$, dan $10 \%$ di atas titik optimum, diperoleh hasil seperti Tabel 4.

Kenaikan suhu maksimum $1 \%$ di atas titik balik akan menurunkan produktivitas padi sebesar $0,09039 \%$ ceteris peribus. Sementara kenaikan 1\% curah hujan akan menurunkan produktivitas padi sebesar 0,00796\% ceteris peribus. Kenaikan suhu maksimum dan curah hujan yang terus menerus akan menambah penurunan produktivitas padi yang semakin besar.

\section{KESIMPULAN DAN SARAN}

Penelitian ini bertujuan untuk menganalisis dampak perubahan iklim terhadap produktivitas padi di Indonesia melalui estimasi kuantitatif. Langkah awal yang dilakukan adalah penentuan kuantifikasi variabel iklim yang sesuai dengan karateristik tanaman 
padi di Indonesia. Dalam penelitian ini membandingkan 4 model dengan spesifikasi variabel iklim yang berbeda dan membandingkan spesifikasi model linear dan non-linear antara produktivitas padi dan variabel iklim.

Model non-linear lebih sesuai digunakaan dalam estimasi dampak perubahan iklim terhadap produktivitas padi di Indonesia daripada model linear. Dilihat dari koefisien determinasi, dari keempat model menunjukkan model 4 yang merupakan model non-linear mempunyai koefisien determinasi yang lebih tinggi dibandingkan model 1, 2, dan 3. Secara rasionalitas hal ini dapat diterima karena variabel iklim optimum akan menguntungkan produktivitas padi, namun jika berlebihan akan menurunkan produktivitas padi. Kuantifiikasi variabel iklim yang yang memberikan dampak terhadap produktivitas padi di Indonesia selama periode 1974-2015 adalah curah hujan dan suhu maksimum. Sensitivitas suhu rata-rata tidak memberikan respon yang signifikan terhadap produktivitas padi karena mengeneralisasikan kondisi iklim dimana iklim bergantung pada musim dan fase perkembangan tanaman padi. Sementara suhu minimum yang dipantau selama periode sampel secara ilmu agronomi berada pada batas kewajaran yakni masih di antara $10^{\circ} \mathrm{C}$ $30^{\circ} \mathrm{C}$. Peningkatan curah hujan dan suhu maksimum mengikuti kurva Inverted
U-Shape, dimana peningkatan suhu akan memberikan dampak positif terhadap produktivitas padi sampai pada titik optimun tertentu. Setelah titik optimum tersebut akan memberikan dampak sebaliknya terhadap produktivitas padi. Titik optimum untuk curah hujan 10,177 inc/tahun, sedangkan suhu maksimum $31,35{ }^{\circ} \mathrm{C}$. Dari simulasi dampak kenaikan curah hujan di atas titik optimum sebesar $1 \%$ akan mengurangi produktivitas padi sebesar 0,00796\%. Sementara dampak kenaikan suhu maksimum di atas titik optimum sebanyak $1 \%$ akan mengurangi produktivitas padi sebanyak $0,09039 \%$.

Perubahan iklim merupakan suatu hal yang tidak dapat dikontrol sepenuhnya. Pemerintah hanya dapat melakukan langkah antisipasi dan adaptasi dampak perubahan iklim terhadap produktivitas padi. Kebijakan pengembangan varietas padi unggul yang tahan terhadap kekeringan, rendaman, dan hama penyakit perlu dilakukan dalam langkah adaptasi tersebut. Selain itu, pengelolaan sumber daya air yang tepat perlu diperhatikan dengan baik sehingga dapat memenuhi kebutuhan air tanaman padi pada kondisi ketersediaan air yang sangat terbatas.

\section{DAFTAR PUSTAKA}

Auffhammer, M., Ramanathan, V., and Vincent, Jefrey R. 2006. Integrated Model Shows that Atmospheric Brown Clouds and Green Houses 
Gases Have Reduced Rice Harvest in India. PNAS 103(52) : 19668-19672

Burke, Marshall B., Miguel, E., Satyanath, S., Dykema, John A., and Lobell, David B. 2009. Warming Increase The Risk of Civil War in Africa. PNAS 106 (49) : 20670-20674.

Deschenes, O., and Greenstone, M. 2007. The Economic Impact of Climate Change : Evidence from Agricultural Profits and Random Fluktuations. The American Review 97(1) : 354385.

Hsiang, Solomon M., Burke, M., and Miguel, E. 2013. Quantifyng The Influence of Climate Human Conflict. Science 341 (6151) : 1235367.

Hsiang, Solomon M., and Burke, M. 2014. Climate, Conflict and Social Stability : What the Evidence Say? Clim Change, 123(1): 39-55.

Kementerian Pertanian. 2012. Pengembangan Asuransi Usaha Tani Padi untuk Antisipasi Perubahan Iklim. Warta Penelitian dan Pengembangan 34(2) : 16-18.

Mendelson, R., Nordhaus, William D., and Shaw, D. 1994. The Impact of Global Warming on Agriculture : A Ricardian Analysis. The American Economic Review 84 (4) : 753-771.
O’Louglin J., Witmer, Frank D.W., Linke, Andrew M., Laing, A., Gettelman, A., and Dudhia, J. 2012. Climate Variablility and Conflict Risk in East Afrika : 1990-2009. PNAS 109(45) : 18344-18349.

Oury, B. 1965. Allowing for Weather in Crop Production Model Building . Journal of Farms of Economic 47 (2) : 270-283.

Peng, S., Huang, J., Sheehy, John E., Laza, Rebecca E., Visperas, Romeo M., Zhong, X., Centeno, Grace S., Khush, Gurdev S., and Cassman, Kenneth G. 2004. Rice Yield Decline With Hight Night Temperature From Global Warming. PNAS 101: 229-238.

Scheffran, J., Brzoska, M., Kominek, J., Link, P.M., Schilling, J. 2012. Climate Change and Violent Conflict. Science 336 (6083) : 869-871.

Schlenker, W., Hanemann, W.M., and Fisher, Anthony C. 2006. The Impact of Global Warming on U.S Agricultures : An Econometric Analysis of Optimal Growing Condition. Review of Economics and Statistics 88 (1) : 113-125.

Schlenker, W., and Roberts, M. J. 2009. Nonlinear Temperature Effects Indicates Severe Damages to U.S. Crop Yields Under Climate Change. 
PNAS 106 (37) : 15594-15598.

Surmaini, E., Runtunuwu, R., Las, I. 2011. Upaya Sektor Pertanian dalam Menghadapi Perubahan Iklim. Jurnal Litbang Pertanian 30 (1) : 1-7.

Tack, J., Barkley, A., and Nalley, Lawton L. 2015. Effect of Warming Temperatures on US Wheat Yields. PNAS 112 (22) : 6931-6936.

Wassmann, R., Jagadish, S.V.K., Heuer, S., Ismail, A., Redona, E., Serraj, R., Singh, R.K., Howel, G., Pathak,
H., and Sumfleth, K. 2009. Climate Change Affecting Rice Production : The Physiological and Agronomic Basis for Possible Adaptation Strategies. Adv.Agron 101 : 59-122.

Welch, JR., Vincent, Jeffrey R., Auffhammer, M., Moya, Piedad F., Doberman, A., and Dawe, D. 2010. Rice Yields in Tropical/ Subtropical Asia Exhibit Large but Opposing Sensitivities to Minimum and Maximum Temperatures. PNAS Vol. 107 (33) : 14562-14567 